\title{
The Role of Financial Literacy as One of the Influences of Financial Behavior
}

\author{
Aprih Santoso ${ }^{1 *}$ and Eka Puspita Sari ${ }^{2}$ \\ ${ }^{1,2}$ University of Semarang \\ Email Address: \\ aprihsantoso@usm.ac.id
}

\begin{abstract}
This study aims to examine the impact of financial literacy and financial attitudes on financial behavior with locus of control as a mediation. This study uses primary data and secondary data and uses purposive sampling method in taking the sample, as many as 89 Postgraduate Students of the Management Study Program, University of Semarang. Data analysis using PLS (Partial Least Square). This study resulted: financial literacy and financial attitudes have a positive and significant impact on financial behavior and locus of control is proven as a mediating variable between the influence of financial literacy and financial attitudes on financial behavior.
\end{abstract}

Keywords: financial, literacy, attitude, locus of control, behavior.

Abstrak: Penelitian bertujuan menguji dampak literasi keuangan dan sikap keuangan terhadap perilaku keuangan dengan locus of control sebagai mediasinya. Penelitian ini memakai data primer dan data sekunder dan memakai metode purposive sampling dalam peengambilan sampelnya, yaitu sebanyak 89 Mahasiswa Pascasarjana Program Studi Manajemen Universitas Semarang. Analisis data memakai PLS (Partial Least Square). Penelitian ini menghasilkan: literasi keuangan dan sikap keuangan berdampak positif dan signifikan pada perilaku keuangan dan locus of control terbukti sebagai variabel mediasi antara pengaruh literasi keuangan dan sikap keuangan pada perilaku keuangan.

Kata Kunci: keuangan, literasi, sikap, locus of control, perilaku.

\section{INTRODUCTION}

Indonesia is entering the era of globalization where the economy is growing and increasing. This has an impact on the financial behavior of the Indonesian people to find solutions to meet their daily needs. a person experiences financial problems due to his irresponsible financial behavior as a result of shopping impulsively and not thinking long. Financial management skills over daily sources of funds including planning, budgeting, managing, controlling, researching and storing are the meaning of financial behavior. Indicators of good financial behavior are seen from the regulation of cash inflows and outflows, credit problems, savings and investment. The problem of failure in personal financial management can cause serious long-term financial problems and negative social life and other social problems (Kusnandar and Rinandiyana, 2018).

Personal assets that are managed by someone intelligently are called financially intelligent modern humans. Having knowledge and doing financial planning is a process 
of achieving life goals, namely a happy and prosperous future through financial management. Without financial planning, life for most people who are already difficult will be even more difficult (Irman, 2018). For every income, proper financial management and supported by good financial knowledge is expected to improve one's social life status. Regardless of the level of one's income, without proper financial management, financial security will definitely be difficult to achieve. Even low financial knowledge can lead to wrong financial planning.

In today's era, in everyday life it turns out that the majority of people are not aware of the importance of personal financial management, because there is still an assumption that only someone with a large income carries out financial planning. However, there are still many individuals with large incomes who do not have an investment plan in their life (Pritazahara and Sriwidodo, 2015). Someone who manages finances now and in the future is a process of learning to be independent in planning their finances (Pritazahara and Sriwidodo, 2015).

Students are one of the components of society with a large enough contribution to the economy in Indonesia, due to high education and should have a good level of financial literacy (Nababan and Sadalia, 2012). However, the current phenomenon, for students who manage their consumption needs independently and undergo various disproportionate economic activities, makes no priority scale formation for their economic activities. Sometimes also in fulfilling their desire for an item, they tend to reduce the allocation of their basic needs (Irman, 2018).

According to information from the administration department, it is known that most of the students of the Postgraduate Program in the Master of Management Program are students who have worked in various companies and earn personal income. With the knowledge gained, working students are expected to be able to control and supervise their monthly finances (Fatimah and Susanti, 2018). Therefore, a positive financial attitude is important to directly implement and evaluate their financial management practices (Pradiningtyas and Lukiastuti, 2019).

The main basis for someone to manage finances effectively in an era like this is one of them by having financial literacy / knowledge according to the writing of (Lusardi, 2007), financial literacy as a combination of understanding between consumers and investors on a financial product, their concepts and abilities as well as confidence in assessing financial risks and opportunities. This is supported by the research of (Laily, 2016), which states that financial literacy is a determinant of a person's financial behavior because it has a significant effect. (Kholilah and Iramani, 2013), whose research states that financial knowledge, financial attitude and locus of control effect a person's financial management behavior. 
Table 1. Gap Research

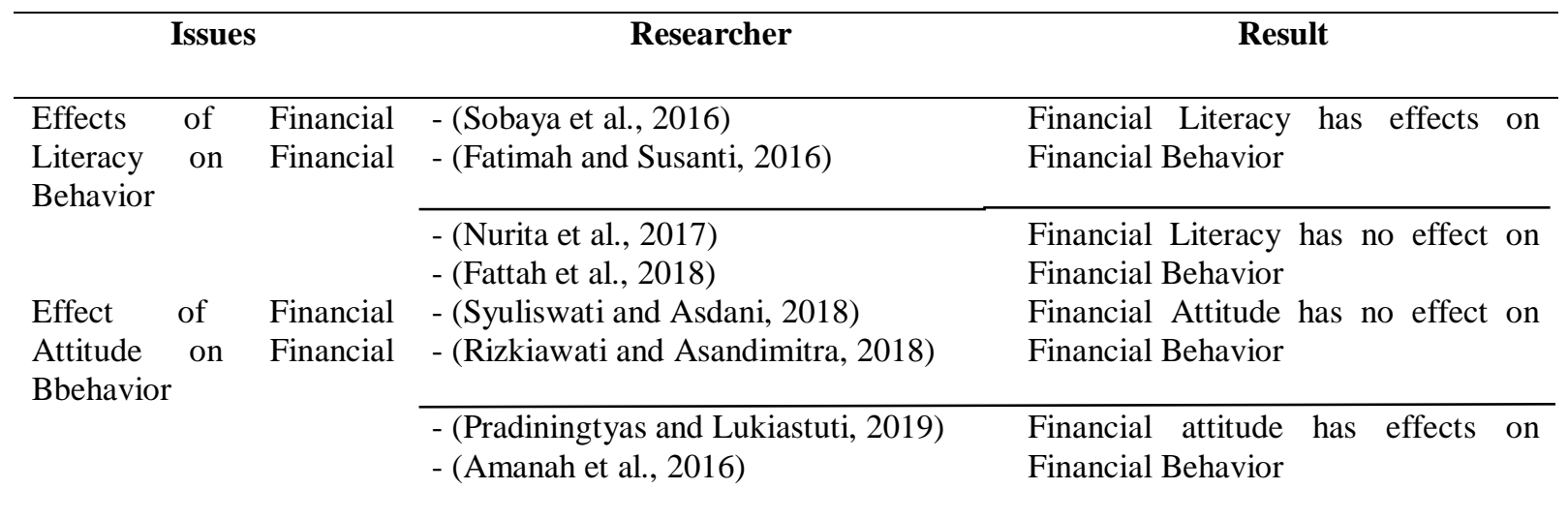

Based on the inconsistency of the results of previous studies regarding the factors that effect financial behavior between financial literacy and financial attitude, the researchers included locus of control as an intervening variable. This is based on the research of (Pradiningtyas and Lukiastuti, 2019) which states that locus of control mediates financial attitude towards a person's financial behavior. (Kholilah and Iramani, 2013) also explains that locus of control mediates financial literacy on financial behavior. This study uses Theory of Planned behavior (TPB) which is related to a person's behavior.

\section{THEORETICAL REVIEW}

Theory of Planned Behavior (TPB). Understanding the way an individual behaves and acts is the application of Planned Behavior Theory (TPB). Behavior does not only depend on a person's intention, but also on other factors that are not under the control of the individual, such as the availability of resources and the opportunity to display the behavior. Attitudes, norms and behavioral control affect a person's decision making. Different reasons as the cause of a person's behavior, so that the existence of this belief as a consequence of his behavior, belief in the expectations of others and things that inhibit this behavior. The principle in this theory is the principle of compatibility which explains attitudes and behavior which are divided into four elements, namely: target, time, context and action and the relationship between attitude and behavior will be maximized if each element functions optimally. This theory clearly describes the relationship between beliefs, attitudes, intentions, and behaviors. Several components in this theory are: behavioral belief, normative belief and control belief. These three components are effected by several variables such as personal factors in the form of general attitudes, personality, life values, emotions, intelligence, social factors such as : gender, age, income, ethnicity, religion and education, information factors such as : media exposure, experience and knowledge. These three components will also effect the intention or will of the individual to behave later.

Financial Behavior. Financial management skills over daily sources of funds including planning, budgeting, managing, controlling, researching and storing are the meaning of financial behavior (Kholilah and Iramani, 2013). Financial behavior is concerned with 
how people treat, manage and use the financial resources available to them. Financial behavior describes how a person treats, manages and uses the resources he has. A person who has responsibility for his financial behavior will use finances effectively by budgeting, saving money, controlling expenses, making investments, saving old age and paying debts on time. Based on some of the definitions of financial behavior above, it can be concluded that financial behavior is a science that explains individual behavior related to how individuals treat, manage, regulate and use the financial resources available to them. Financial behavior of a person who is right will get used to being responsible for effectively using his money, such as: preparing a budget, paying attention to financing and saving money and controlling financing, investing and financing debt on time, while individuals who fail to manage their personal finances can have serious long-term consequences. not only for that person but also for the company and the community (Dwiastanti, 2015). Financial planning is not only for high-income people but for all high and low-income groups it is necessary to make financial planning for future welfare and life goals, but what is different is how it is allocated in financial management.

Financial Literacy. Literacy is defined as a person's expertise in speak, learning, write, count and solve problems at the level of proficiency required in the individual, family and society. Financial literacy is a general description of the ability to use and manage finances. The Australian Securities and investment commission, to explore and find out how much a person's financial literacy can use benchmarks: 1) A person's knowledge of the value of an item and the priority scale in his life 2) Budgeting, savings and how to manage finances 3) Credit management 4) The importance of insurance and protecting against risk 5) Fundamentals of investing 6) Retirement planning 7) Utilization of spending and comparing products where to go for advice and additional guidance and support information on how to identify potential conflicts over utility (prioritization). (Widayati, 2010), financial literacy is measured by: 1) Arranging or planning a budget for income to be received. 2) Compiling and planning a budget for expenses. 3) Understanding of inflation. 4) Understanding the nominal value of money. 5) Compliance with expenditure budget plans. 6). Understanding the real value of money

Financial attitude. Financial attitude is the application of financial rules that are used to maintain values and achievements through wise decisions and manage financial resources (Pankow, 2012). Financial attitude can be reflected by 3 main components consisting of: cognitive, affective (feeling) and behavior or action. (Pankow, 2012), financial attitude is an opinion, assessment and measure of a person's state of mind, towards his personal finances.

Locus of control. Locus of control is a person's perspective on an event whether or not he can control the events that occur to him. Individuals with internal locus of control tend to think that their skills, abilities, and efforts are more determining what they will get in life. Individuals who have the belief that their fate or life are under their own control are said to have internal locus of control. Meanwhile, individuals with external locus of control tend to think that their lives depend on external forces such as fate, destiny, luck and other people in power. Individuals who believe that the environment has control over fate or events that occur in their life are said to have an external locus of control. Thus the higher 
the level of internal locus of control possessed by an individual, the better his financial knowledge will be. Locus of control is also a psychological concept regarding a person's belief in the extent to which they can control events / events that affect them (Cobb et al, 2013), where locus of control represents a controller or being controlled by external events (Ziemkiewiez et al., 2011). The more responsible the individual is, the more careful he will be in managing his finances. The higher the locus of control, the better the financial behavior will be (Mien and Thao, 2015).

The Effect Financial Literacy on Locus of Control. (Sabri, 2011), Financial literacy is a person who needs knowledge to stay alive in society according to his lifestyle. This basic knowledge involves knowing and understanding the complex principles of spending, saving and investing. In dealing with personal finance problems systematically and successfully, individuals need a knowledge of money. Financial literacy can not only help individuals use money wisely, individuals are often faced with trade-off situations where individuals are forced to sacrifice one's interests for the sake of others (Pradiningtyas and Lukiastuti, 2019). Good financial literacy will make individuals better too. This is in line with research conducted by (Pritazahara and Sriwidodo, 2015), which states that financial knowledge has a positive influence on individual locus of control. (Pradiningtyas and Lukiastuti, 2019) states that financial literacy has an impact on locus of control, so in this study the hypothesis is;

\section{H1: Financial Literacy effect on Locus of Control.}

The Effect of Financial Attitude on Locus of Control. Financial attitude is more directed to the way of thinking of individuals, income and individual judgments about financial practices. Individuals who are rational and confident in financial matters will affect their self-control. Because, locus of control reflects on the individual belief that he can control events in his life world. This is in line with the research of (Pradiningtyas and Lukiastuti, 2019) which states that financial attitude has a positive effect on locus of control. Other research, support (Herdjiono and Damanik, 2016) and (Pradiningtyas and Lukiastuti, 2019) states that there is a positive relationship between financial attitudes and financial levels. Financial attitude can also be a factor that effect how a person controls himself with the results he gets. The research hypotheses are;

\section{H2: Financial Attitude effect Locus of Control.}

The Effect of Financial Literacy on Financial Behavior. Financial Literacy has the meaning of individual expertise in reading, write and speak, calculate and solve problems at the level of proficiency required in an individual, family and society (Remund, 2010). Financial Literacy is the level of knowledge, skills, and public confidence in relation to financial institutions and their products and services that are issued in the index measure parameter. Financial literacy is useful in encouraging the provision of understanding of financial management and the opportunity to achieve a more prosperous life in the future. research by (Sobaya et al., 2016) states that financial literacy is very important because individuals who have good financial planning can not only make savings but also increase asset value. Financial literacy effects individual financial planning. (Hamdani, 2018) and 
(Pradiningtyas and Lukiastuti, 2019) states that the higher the level of one financial knowledge and abilities, the wiser they will be in managing, making decisions and planning. The research hypothesis is:

H3: Financial Literacy effect Financial Behavior.

The Effect of Financial Attitude on Financial Behavior. Financial attitude is considered equally important in the management of personal financial finances. By having a good financial attitude, individuals will be able to manage finances well. Without implementing this, it will be difficult for individuals who have extra money to allocate for savings, let alone have the capital to invest (PradIningtyas and Lukiastuti, 2019). (Herdjiono and Damanik, 2016) explains that attitudes are measured by individual responses to their opinions on money, while financial management behavior leads to how individuals behave in relation to personal finances as measured by these actions. (Puneet and Medhury, 2014) and (Pradiningtyas and Lukiastuti, 2019) state that financial attitudes significantly effect financial behavior. On the basis of this, the hypothesis is:

H4: Financial Attitude effect Financial Behavior.

The Effect of Locus of Control on Financial Behavior. Locus of control is a person's tendency to believe internally and externally from within. Locus of control in financial management is an activity to take actions in the form of protection - self-protection such as frugality, controlling consumptive behavior and so on (Pradiningtyas and Lukiasttuti, 2019). (Dwiastianti, 2017), (Arifin, 2017), (Arianti, 2017), (Hikmawati and Alamsyah, 2018), (Alexander and Pamungkas, 2019), (Pradiningtyas and Lukiastuti, 2019) research which also states that locus of control has an impact on financial behavior. On the basis of this, the hypothesis is:

H5: Locus Control effect Financial Behavior. 


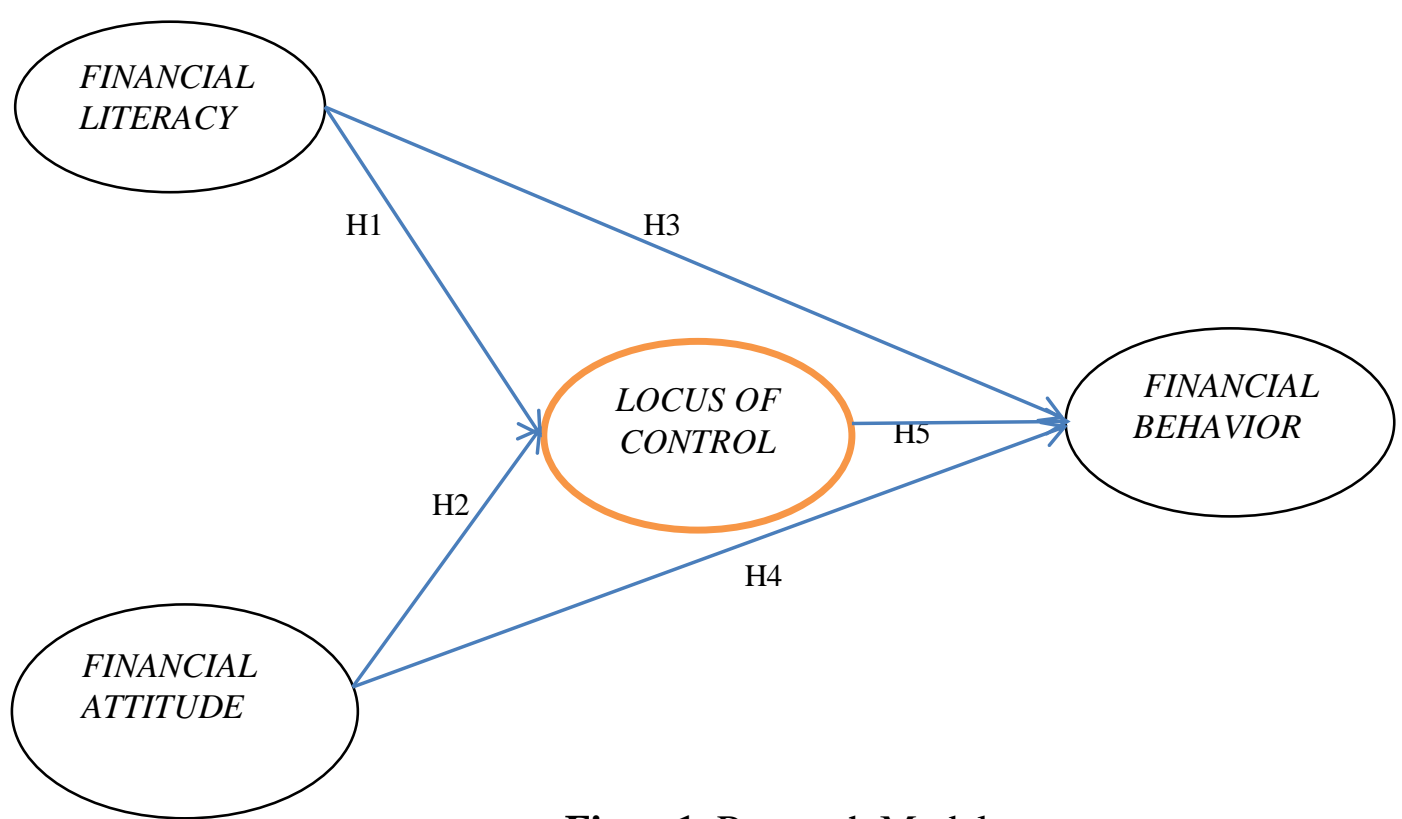

Figur 1. Research Model

\section{METHODS}

Types of research. This type of research is an explanatory type, to test the hypothesis and to explain the effect of the variables, namely the variable financial literacy, financial attitude, financial behavior with locus of control as the mediating variable. The object of his research is active students of the post-graduate Magister Management program in Semarang University. The samples and respondents in this study were the post-graduate students of the Magister Management program at the Semarang University who were still active with a total of 162 students.

\section{Operational definition}

Table 2. Operational Definition

\begin{tabular}{|c|c|c|}
\hline Variable & Definition & Indikacor \\
\hline $\begin{array}{l}\text { Financial } \\
\text { Literacy }\end{array}$ & $\begin{array}{l}\text { A combination of understanding between } \\
\text { consumers and investors about financial } \\
\text { products, such as pension funds, banking, } \\
\text { investment and insurance, their concepts and } \\
\text { abilities as well as confidence in assessing } \\
\text { financial risks and opportunities (Sobaya, 2016) }\end{array}$ & $\begin{array}{l}\text { 1. Knowledge Retirement } \\
\text { 2. Banking Knowledge } \\
\text { 3. Investment Knowledge } \\
\text { 4. Insurance knowledge } \\
\text { 5. Ability and confidence } \\
\text { in assessing financial } \\
\text { opportunities }\end{array}$ \\
\hline $\begin{array}{l}\text { Financial } \\
\text { Attitude }\end{array}$ & $\begin{array}{l}\text { The thoughts, opinions and thoughts of a person } \\
\text { who are carried out with the attitude of setting } \\
\text { aside funds for the future regularly, writing } \\
\text { financial goals or targets, saving money by } \\
\text { prioritizing purchases of primary needs, writing } \\
\text { budget plans and financial planning (Listiani, }\end{array}$ & $\begin{array}{l}\text { 1. Set aside funds for the future } \\
\text { 2. Record financial goals / targets } \\
\text { 3. Save money, prioritizing your primary } \\
\text { needs } \\
\text { 4. Plan a budget } \\
\text { 5. Perform financial planning }\end{array}$ \\
\hline
\end{tabular}




\begin{tabular}{|c|c|c|}
\hline \multirow{8}{*}{$\begin{array}{l}\text { Locus } \\
\text { control }\end{array}$} & \multicolumn{2}{|l|}{ 2017) } \\
\hline & Psychological concept where someone who has & 1. Confidence in personal skills / abilities \\
\hline & more internal locus of control believes that skills, & 2. Belief in effort and hard work \\
\hline & abilities and efforts can more determine what & 3. Belief in help from others \\
\hline & they get in their life. Meanwhile, someone who & 4. Belief in luck \\
\hline & has an external locus of control believes that & 5. Belief in destiny \\
\hline & their external power such as help from others, & 6. Belief in fate \\
\hline & $\begin{array}{l}\text { luck, destiny, fate determines their life. } \\
\text { (Ziemkiewicz et al., 2011) }\end{array}$ & \\
\hline \multirow{5}{*}{$\begin{array}{l}\text { Financial } \\
\text { behavior }\end{array}$} & How does one manage, treat, and use financial & 1. Pay bills on time \\
\hline & resources properly. someone who behaves & 2. Provide unexpected funds \\
\hline & financially responsibly will succeed in using his & 3. Recording expenses and spending \\
\hline & money like paying bills on time, providing & 4. Budgeting expenditures \\
\hline & $\begin{array}{l}\text { unexpected funds, controlling spending by } \\
\text { recording expenses and expenditures, making } \\
\text { budgets, saving periodically (Nababan and } \\
\text { Sadalia, 2012) }\end{array}$ & 5.Save periodically \\
\hline
\end{tabular}

Method of Analysis. This study uses quantitative data analysis. Researchers used Structural Equational Modeling (SEM) analysis using PLS. Hypothesis testing using bootstrap resampling method ( $\mathrm{t}$ test).

\section{RESULT AND DISCUSSION}

\section{Validity and Reliability Test}

Table 3. Outer Loading SmartPLS

\begin{tabular}{lrrr}
\hline INDICATOR & VALIDITY & INDICATOR & VALIDITY \\
\hline X I.I & $-0,571$ & Y 1.1 & 0,212 \\
X 1.2 & 0,791 & Y 1.2 & 0,250 \\
X 1.3 & 0,233 & Y 1.3 & 0,021 \\
X 1.4 & 0,649 & Y 1.4 & 0,877 \\
X 1.5 & 0,876 & Y 1.5 & 0,837 \\
X 2.1 & 0,886 & Y 1.6 & 0,869 \\
X 2.2 & 0,742 & Y 2.1 & 0,599 \\
X 2.3 & 0,741 & Y 2.2 & 0,422 \\
X 2.4 & 0,696 & Y 2.3 & 0,396 \\
X 2.5 & 0.782 & Y 2.4 & 0,951 \\
& & Y 2.5 & 0,198 \\
\hline
\end{tabular}




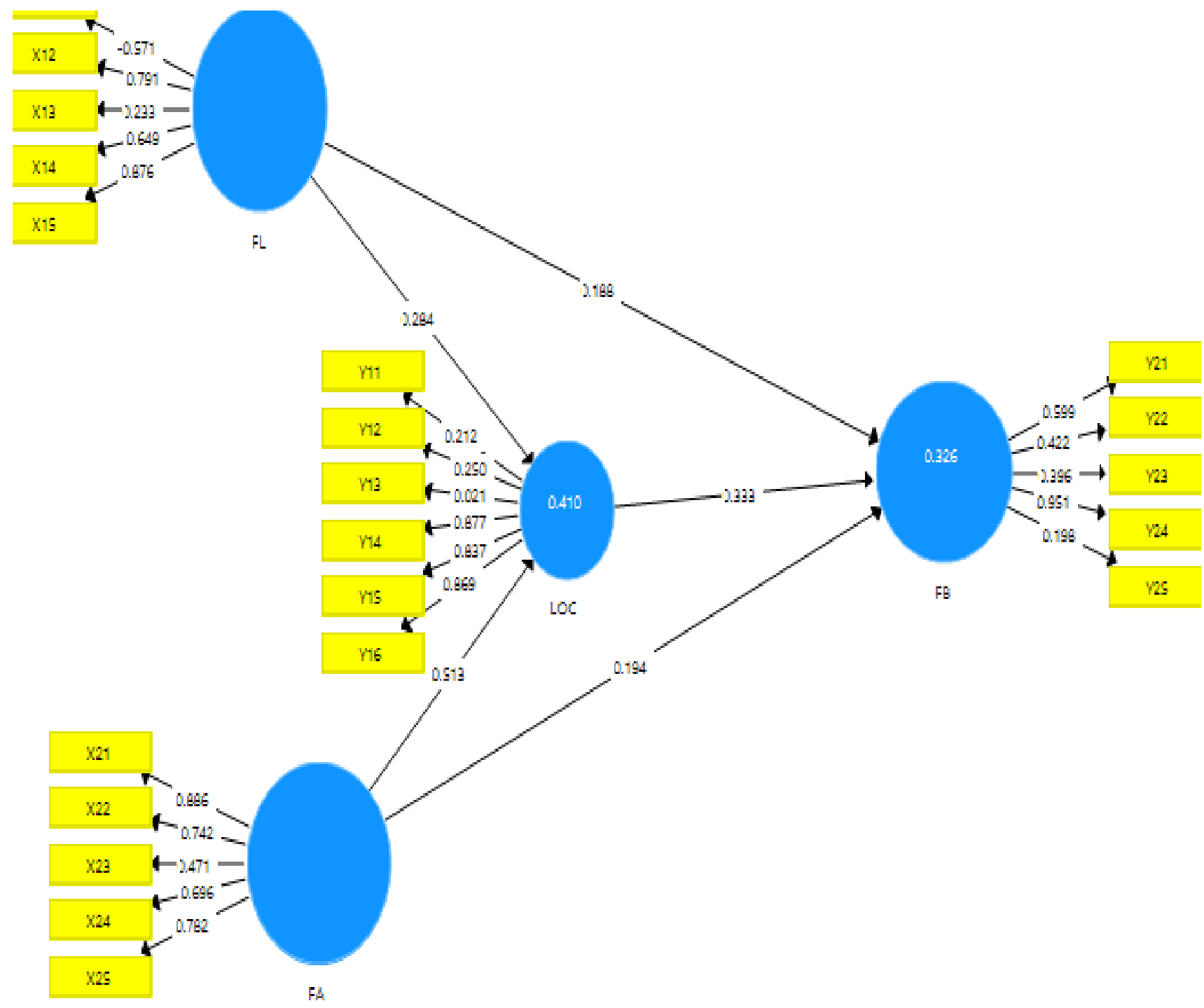

Figur 2. Outer Loading Factor of Model Struktural SmartPLS

Tables and pictures show the outer loading factor show that the indicators used to measure each variable show a value above 0.50 , so all variables can be used. However, some variables show a value below 0.50 , which means that they cannot be used, so they must be removed. 


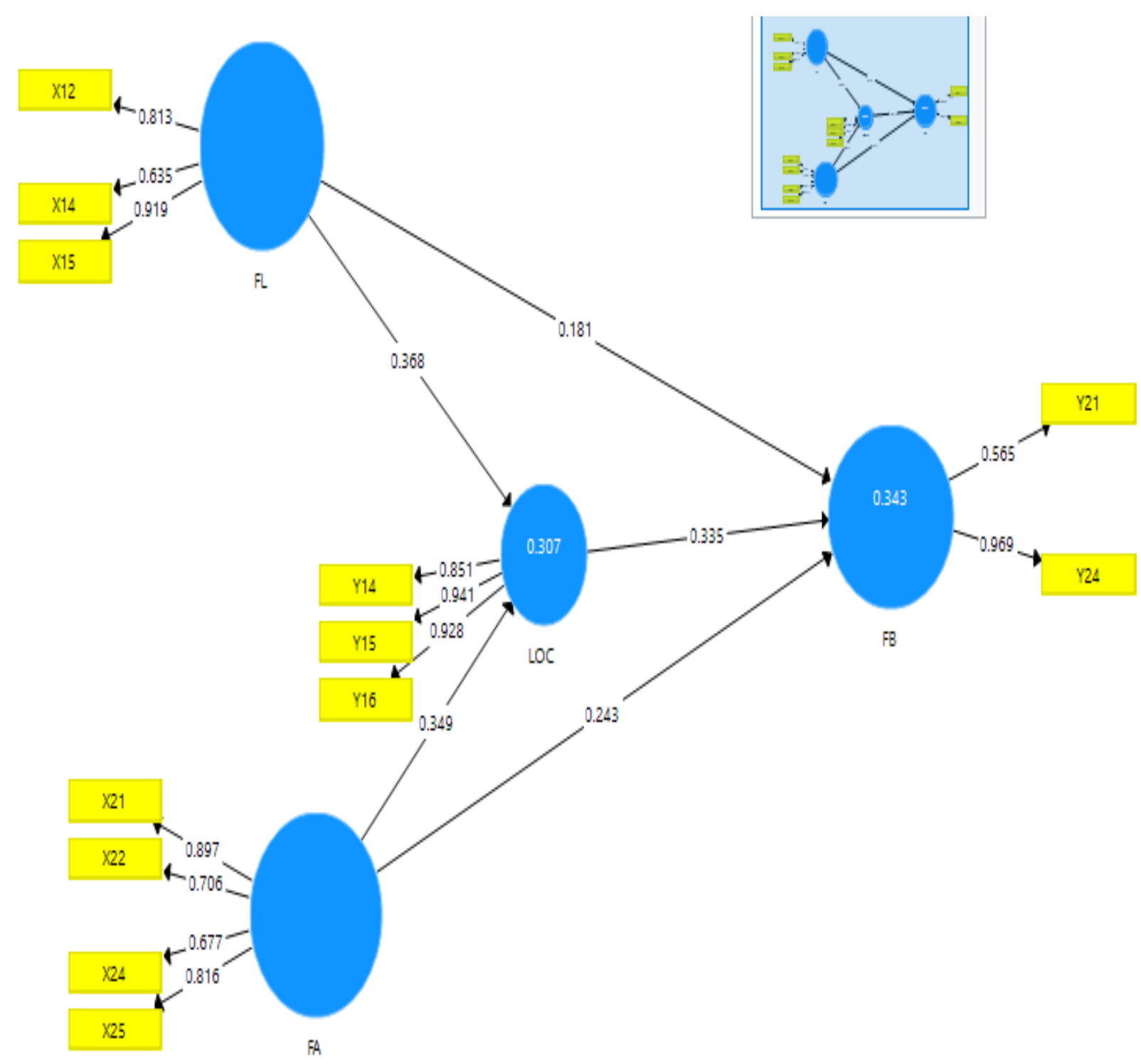

Figur 3. Outer Loading Factor of Model Struktural SmartPLS (setelah Drop)

Table 4. Output Construct Reliability and Validity Smart PLS

\begin{tabular}{ccc}
\hline Variabel & Composite Reliability & Average Variance Extracted \\
\hline Financial Literacy & 0,859 & 0,607 \\
Financial Atitude & 0,760 & 0,629 \\
Locus Of Control & 0,837 & 0,636 \\
Financial Behavior & 0,933 & 0,824 \\
\hline
\end{tabular}

Unidimensionality model testing is the last measurement step to confirm there is a problem. The unidimensionality test was carried out using the composite reliability and AVE indicators with a cut-off value of 0.6. This shows that all constructs have a composite reliability value above 0.7 , so that there are no reliability or unidimensionality problems found in the model formed. 


\section{Coefficient of Determination}

Table 5. Output R Square Smart PLS

\begin{tabular}{cc}
\hline Variable & R square Adjusted \\
\hline FB & 0,320 \\
LOC & 0,291 \\
\hline
\end{tabular}

Table 5, shows that $\mathrm{R}$ square is the endogenous variable in the equation model. Q2 is worth between $0>\mathrm{Q} 2>1$, and closer to 1 so the model is good. The magnitude of Q2 is equivalent to the total coefficient of determination in the path analysis. The locus of control variable has an $\mathrm{R} 2$ value of 0.291 , meaning that $29.1 \%$ of the locus of control variable can be explained by financial literacy and financial attitude variables, while the remaining $70.9 \%$ is explained by other variables outside the model. The financial behavior variable has a R2 value of 0.320 , meaning that $32 \%$ of the financial behavior variable caused by the collaboration of financial attitude variables and financial literacy, as for the remaining $68 \%$ is described by variables other than in this study.

\section{Indirect Effect dan Total Effect}

Table 6. Output Matrik Total Indirect Effect SmartPLS

\begin{tabular}{cccc}
\hline Matrix & Original sample & T statistic & P Value \\
\hline FA -> FB & 0,117 & 2,056 & 0,040 \\
FL -> FB & 0,123 & 1,993 & 0,047 \\
\hline
\end{tabular}

The indirect effect matrix, it can be concluded that there is an indirect effect between the variables:

1. Financial attitude effect financial behavior. Financial attitude $\rightarrow$ financial behavior $=$ 0,040 and $t$ statistic $=2,056$ at significant of $5 \%$

2. Financial literacy towards financial behavior. Financial literacy $\rightarrow$ Financial behavior= 0,047 and $t$ statistic $=1,993$ at significant of $5 \%$

Table 7. Output Total Effect SmartPLS

\begin{tabular}{lccc}
\hline \multicolumn{1}{c}{ Matric } & Original Sample & t statistic & P Values \\
\hline FA $->$ FB & 0,360 & 3,816 & 0,000 \\
FA -> LOC & 0,349 & 3,919 & 0,000 \\
FL -> FB & 0,305 & 3,137 & 0,002 \\
FL -> LOC & 0,368 & 3,518 & 0,000 \\
LOC -> FB & 0,324 & 2,444 & 0,015 \\
\hline
\end{tabular}

Testing pathways that effect investment behavior, is: (1) Financial attitude path $\rightarrow$ financial behavior $=0,360$ and $t$-stat. $=3,816$ and significant of 5\%. (2). Path of financial attitude $\rightarrow$ locus of control $=0,349$ and t-stat. $=3,919$ and significant of $5 \%$. (3) Financial literacy $\rightarrow$ financial behavior $=0,305$ and t-stat. $=3,137$ and significant of $5 \%$. (4) Financial literacy $\rightarrow$ locus of control $=0,368$ and t-stat. $=3,518$ and significant of 5\%. (5) Locus of control $\rightarrow$ financial behavior $=0,324$ and t-stat. $=2,444$ and significant of $5 \%$ 
Locus of control is an intervening variable that can be calculated using the Sobel Test as follows: (1) Path of financial literacy $\rightarrow$ financial behavior $=0,305$. (2) Path of financial literacy $\rightarrow$ locus of control $\rightarrow$ financial behavior at indirect effect $=0,111$ or total effect $=0,368 \times 0,303=0,111$. $Z$ value $(2,00)>1,96$ (absolute $Z$ value) so a significant indirect effect of financial literacy on locus of control. This proves that the locus of control variable is an intervening variable. (3) Path of financial attitude $\rightarrow$ financial behavior sebesar 0,360. (4) Path of financial attitude $\rightarrow$ locus of control $\rightarrow$ financial behavior of indirect effect $=0,663$ or total effect $=0,360 \times 0,303=0,663$.

$\mathrm{Z}$ value $(2,07)>1,96$ (absolute $\mathrm{Z}$ value) so a significant indirect effect of financial attitude on locus of control so that significantly there is no indirect effect of financial attitude on locus of control. This proves that the locus of control variable is not an intervening variable.

Table 8. Output Path Coefficients Bootstrap SmartPLS

\begin{tabular}{lccc}
\hline \multicolumn{1}{c}{ Matrik } & Original sample & t Statistik & P Values \\
\hline FA -> FB & 0,243 & 2,262 & 0,024 \\
FA -> LOC & 0,349 & 3,950 & 0,000 \\
FL -> FB & 0,181 & 1,984 & 0,048 \\
FL -> LOC & 0,368 & 3,527 & 0,000 \\
LOC -> FB & 0,335 & 2,263 & 0,024 \\
\hline
\end{tabular}

Hypothesis testing 1: Financial Literacy has an effect on Locus Of Control. The results of the first hypothesis test state that the correlation between financial literacy variables on locus of control shows a path coefficient value of $0.368>$ a cut-off value of $0.50(\mathrm{t}=3.527 ; \mathrm{p}=0.000)$. This result means that financial literacy has an impact significantly to locus of control.

Hypothesis testing 2: Financial Attitude affects the Locus of control. The results of the second hypothesis test state that the correlation between financial attitude variable on locus of control shows a path coefficient of $0.349>$ a cut-off value of $0.50(t=3,950 ; p=$ 0,000). This result means that financial attitude has an impact significantly to locus of control.

Hypothesis testing 3: Financial Literacy affects financial behavior. The results of the third hypothesis test state that the correlation between financial literacy variable on financial behavior shows a path coefficient of $0.181>$ a cut-off value of $0.50(t=1.984 ; p$ $=0.048)$. This result means that financial literacy has an impact significant to financial behavior.

Hypothesis testing 4: Financial Attitude has an effect on Financial Behavior. The results of the fourth hypothesis test state that the correlation between financial attitude variable on locus of control shows a path coefficient of $0.243>$ a cut-off value of $0.50(\mathrm{t}=$ $2.262 ; \mathrm{p}=0.024)$. This result means that financial attitude has an impact significant on financial behavior. 
Hypothesis testing 5: Locus of Control effect Financial Behavior. The results of the fifth hypothesis test state that the correlation between locus of control variable on financial behavior shows a path coefficient value of $0.335>$ a cut-off value of $0.50(\mathrm{t}=2.263 ; \mathrm{p}=$ 0.024). This result means that locus of control has an impact significant on financial behavior.

\section{DISSCUSION}

The Effect of Financial Literacy on Locus of Control. The results of the Bootstrap Output Path Coefficient, it is known that the relationship between financial literacy has an impact significant on locus of control. Most of the respondents considered that financial literacy for Postgraduate Students of the Master of Management Study Program at the University of Semarang falls into the high criteria. The highest indicator of financial literacy is the indicator of banking knowledge. And the lowest indicator is an indicator of retirement knowledge. This results, justification can be made to build a positive attitude to receive education about literacy in financial aspects among students and are expected to have positive financial behavior for financial prosperity in the future. The results of this study are support (Hamdani, 2018), (Pradiningtyas and Lukiastuti, 2019) which states that sufficient knowledge of financial concepts and good personal finance behaior will produce people who are wiser in managing their personal finances. This hypothesis and discussion proven, it is important for related parties to foster a positive attitude for students to receive education, not only on financial knowledge about retirement but also for other financial aspects.

The Effect of Financial Attitude on Locus Of Control. The results of the Bootstrap Path Coefficient Output, it is known that the relationship between financial attitude variables has an impact significant on locus of control. Most of the respondents considered that the financial attitude of students was included in the High criteria. The highest indicator of financial attitude is an indicator of setting aside funds for savings. And the lowest indicator is an indicator that records the financial budget plan. This results it can be justified that it is necessary to foster a positive financial attitude of students. This is in accordance with the research of (Pradiningtyas and Lukiastuti, 2019), (Humaira and Sagoro, 2018) and (Amanah et al., 2016) which state in their research that financial attitude effect financial behavior. The justification for this hypothesis and discussion is that financial attitude, which is a person's thoughts, opinions and opinions on their personal financial situation, effect a person's locus of control.

The Effect of Financial Literacy on Financial Behavior. The results of the Bootstrap Output Path Coefficient, it is known that the relationship between financial literacy variables has an impact significant on financial behavior. Most of the respondents considered that financial literacy for students was included in the high criteria. The highest indicator of financial literacy is the indicator of banking knowledge. And the lowest indicator is an indicator of retirement knowledge. This results, it can be justified that forming a positive attitude to deepen financial literacy through facilities from the campus or other institutions among students to be able to attract students to behave better financially. (Hamdani, 2018); (Sobaya et al., 2016); (Laily, 2017), (Pritazahara, 2015), 
(Arlinawati et al., 2020), (Humaira and Sagoro, 2018), (Pradiningtyas and Lukiastuti, 2019) and (Afdilla et al., 2020) who state in their research that financial literacy effects financial behavior. Justification for the proof of this hypothesis and discussion, it is important for students to deepen knowledge of financial aspects in banking, investment, pension, especially pension knowledge as knowledge of how to prepare pension funds in the future and effect wiser financial behavior.

The Effect of Financial Attitude on Financial Behavior. The results of the Bootstrap Path Coefficient Output, it is known that the relationship between financial attitude has an impact significant on financial behavior. Most of the respondents considered that the financial attitude of the students was included in the high criteria. The highest indicator of financial attitude is an indicator of recording financial budgets. And the lowest indicator is an indicator in making the savings needed to prioritize spending for primary needs. This results it can be justified that the need for self-discipline and building awareness of the importance of good personal financial behavior by not only writing a financial budget but also how important it is to prioritize the main needs in making financial savings. (Pradiningtyas and Lukiastuti, 2019), (Afdilla et al., 2020) and (Amanah et al., 2016) which states that financial attitude effect on financial behavior.

The Effect of Locus Of Control on Financial Behavior. The results of the Bootstrap Output Path Coefficient, it is known that the relationship between the locus of control variable has an impact significant on financial behavior. Most of the respondents considered that the locus of control of students was included in the High criteria and included external locus of control. The highest indicator of locus of control is an indicator of luck which determines one's success. The lowest indicator is an indicator of the belief that help from others determines one's success. This results, it can be justified from the respondent's statement that success is achieved from one's own luck (external locus of control). This is in accordance with the research of (Kusnandar and Rinandiyana, 2018) and (Kholilah and Iramani, 2013) which state that locus of control mediates financial literacy on financial behavior. Justification for the proof of this hypothesis and discussion, it is important for students to apply what events we face, whether positive (success) or negative (failure). If it is positive, it is better if we apply internal locus of control, on the other hand, if it is negative, it would be better if we apply an external locus of control.

\section{CONCLUSION}

The results showed financial literacy and financial attitudes has an impact significant on financial behavior. Locus of control is proven as a mediating variable between financial literacy towards financial behavior and financial attitude towards financial behavior.

\section{REFERENCES}

Afdilla, UB., Wahono, B. dan Khoirul, M.ABS, (2020). Pengaruh Pengetahuan Keuangan, Sikap Keuangan Dan Kepribadian Terhadap Perilaku Manajeman Keuangan Pada Pelaku Umkm Penghasil Susu Di Pujon (Studi Kasus Pada Koperasi Susu Sae Pujon). e-Jurnal Riset Manajemen PRODI MANAJEMEN. 9 (8).72-89. 
Alexander, B. dan Pamungkas, AS. (2019). Pengaruh Pengetahuan Keuangan, Lokus Pengendalian Dan Pendapatan Terhadap Perilaku Keuangan. Jurnal Manajerial Dan Kewirausahaan UNTAR. 1(2).1-14.

Amanah, E., Rahadian, D., Iradianty, A. (2016). Pengaruh Financial Knowledge, Financial Attitude dan External Locus of Control terhadap Personal Financial Management Behavior pada Mahsiswa S1 Universitas Telkom. e-Proceeding Of Management. 3(2), 1228-1235.

Arianti, B. F. (2017). The Influence of Financial Literacy, Financial Behavior and Income on Investment Decision. European Research Studies Journal, 20(3A), 635-648.

Arifin, A. Z. (2017). The Influence of Financial Knowledge, Control and Income on Individual Financial Behavior. European Research Studies Journal, XX (3A), 635648.

Arlinawati, M., Sawitri, NN. and Utomo, KW. (2020). The Sensitivity of Financial Position and Financial Behavior of Young Workers. Jurnal Manajemen UNTAR. XXIV(02). 232-249.

Cobb, Clark . Deborah A. Sonja C Kassenboehmer and Mathias G Sinning. (2013). Locus of Control and Savings, IZA DP No. 7837. Retrieved from ftp.iza.org/dp4750.pdf.

Dwiastanti, Anis. (2015). Financial Literacy as The Foundation for individual Financial behavior. Journal of Education and Practise. 6(33). 99-105.

Fatimah, N dan Susanti. (2018). Pengaruh pembelajaran Akuntansi Keuangan, Literasi keuangan dan Pendapatan terhadap perilaku keuangan Mahasiswa Fakultas Ekonomi Universitas Muhammadiyah Gresik. Jurnal Pendidikan Akuntansi (JPAK). 6(01). 48-57.

Hamdani, Mailani. (2018). Analisis Tingkat Literasi Keuangan dan pengaruhnya terhadap Perilaku Keuangan pada mahasiswa Prodi Manajemen Universitas Terbuka. Jurnal Bakti Masyarakat Indonesia. 1(01). 139-145.

Herdjiono, I. dan Damanik, LA. (2016). Pengaruh Financial Attitude, Financial knowledge, parental income terhadap financial management behavior. Jurnal Manajemen Teori dan Terapan. 9(3). 226-241.

Hikmawati, N. K., and Alamsyah, D. P. (2018). The digital company based on competitive strategy. Proceedings of the 3rd International Conference on Informatics and Computing, ICIC 2018, 2001. https://doi.org/10.1109/IAC.2018.8780516 H.

Humaira, I. and Sagoro, Em. (2018). The Influence Of Financial Knowledge, Financial Attitude, And Personality Towards Financial Management Behavior On Small Medium Enterprises At Batik Craft Of Bantul Regency. Jurnal Nominal. VII (1). 96110.

Irman, Mimeliantesa. (2018). Analisis faktor-faktor yang mempengaruhi Financial Literacy di kalangan mahasiswa Universitas Muhammadiyah Riau (UMRI) Pekanbaru. Journal of Economic, Business and Accounting (COSTING). 1(2). 180197.

Kusnandar, D. dan Rinandiyana, L (2018). Apakah menjadi kekinian merubah perilaku keuangan generasi milenial di Universitas Siliwangi. Jurnal Ekonomi Manajemen. 4(01). 55-60.

Kholilah, N.A. Iramani, R.M. (2013). Studi Financial Management Behavior Pada Masyarakat Surabaya. Journal of Business and Banking. 3(1), 69-80. 
Laily, Nujmatul. (2013). Pengaruh Literasi Keuangan terhadap perilaku Keuangan Mahasiswa dalam Mengelola Keuangan. Jurnal Pendidikan Akuntansi. Universitas Malang. 1(4). 27-38.

Mien and Thao, (2015). Factors Affecting Personal Finance Management Behaviors: Evidence from Vietnam. Proceedings of the second Asia Pasific Conference on Global Business, Economics, Finance and Social Sciences (Ap15 Vietnam Conference) ISBN: 978-1-63415-833-6.

Nababan, D dan Sadalia, I. (2013). Analisis Personal Financial Literacy dan Financial Behavior Mahasiswa strata 1 Fakultas Ekonomi universitas Sumatera. Utara. Jurnal Media Informasi Manajemen. 1(1). 75-84.

Pankow, Debra. (2012). Financial Values, Attitudes and Goals. NDSU Extension Services.

Pradiningtyas, T., dan Lukiastuti, F. (2019). Pengaruh pengetahuan keuangan dan sikap terhadap Locus of Control dan Perilaku Pengelolaan Keuangan Mahasiswa Ekonomi. Jurnal Minds: Manajemen Ide dan Inspirasi. 6(1), 96-112.

Pritazahara, R. dan Sriwidodo, U. (2015). Pengaruh Pengetahuan Keuangan dan Pengalaman keuangan terhadap Perilaku Perencanaan Investasi dengan Self Control Sebagai Variabel Moderating. Jurnal Ekonomi dan kewirausahaan, 15(1), 28 - 37.

Syulistwati, A. dan Asdani, A. (2018). Analisis Tingkat Pengetahuan, Sikap keuangan Pribadi dan Perilaku Keuangan Pribadi Mahasiswa Jurusan Akuntansi Politeknik Negeri Malang. Jurnal Akuntansi Bisnis \& Manajemen ABM). 25(1), 43-55.

Pradiningtyas, TE dan Lukiastuti, F. (2019). Pengaruh Pengetahuan Keuangan Dan Sikap Keuangan Terhadap Locus Of Control Dan Perilaku Pengelolaan Keuangan Mahasiswa Ekonomi. Jurnal Minds: Manajemen Ide dan Inspirasi. 6 (1). 96-112.

Puneet, B.Y, Medhury. (2014). An empirical Analysis of Intern Linkages Between Financial Attitudes, Financial Behavior and Financial Knowledge Of salaried Individuals. Indian Journal of Commerce \& Management studies, 5 (3). 58-64.

Rizkiawati, NL dan Asandimitra, N. (2018). Pengaruh demografi, financial knowledge, financial attitudes, locus of control and financial efficacy terhadap financial management behavior masyarakat Surabaya. Jurnal Ilmu Manajemen. 6(3). 93-107.

Sabri, M. F. (2011). Pathways To Financial Success: Determinants Of Financial Literacy And Financial Well - Being Among Young Adults. Graduate Theses and Dissertations. Iowa State University.

Sobaya, S.,. Hidayanto F.M, Safitri, J. (2016). Pengaruh Literasi Keuangan dan Lingkungan Sosial terhadap perencanaan Keuangan pegawai di Universitas Islam Indonesia Yogyakarta. Madania: Jurnal Kajian Keislaman, 20(1), 115-128.

Widayati, Irin (2012). Faktor - faktor yang mempengaruhi Literasi Finansial Mahasiswa Fakultas Ekonomi dan Bisnis Universitas Brawijaya. ASSET: Jurnal Akuntansi dan Pendidikan, 1(1), 89-99.

Z Ziemkiewicz, C., Crouser, RJ., Ashley Rye Yauilla, AR., Su, SL. Ribarsky, W. and Chang, R. (2011). How Locus of Control Influences Compatibility with Visualization Style. Visual Analytics Science and Technology. 81-90. retrieved from http://ieeexplore.ieee.org. 